\title{
EVALUATION OF TOTAL PHENOLIC, FLAVONOID CONTENT, ANTIOXIDANT AND IN VITRO ANTILITHOGENESIS ACTIVITIES OF CHIVES LEAF (Allium schoenoprasum, L.)
}

\author{
S.M. Sinaga ${ }^{1,}$, S. Sudarmi ${ }^{1}$, I. Iksen ${ }^{1}$, K. Kevin ${ }^{1}$ and M.P. Sari ${ }^{1}$ \\ ${ }^{1}$ Department of Pharmaceutical Chemistry, Faculty of Pharmacy, Universitas Sumatera Utara, \\ Medan-20155, Indonesia \\ *E-mail : sitimorinsinaga28@gmail.com
}

\begin{abstract}
Natural resources and traditional medicines are important assets that need to be explored, researched, developed and optimized for their use. One of the natural resources that can be used as medicinal ingredients is chives (Allium schoenoprasum, L.), especially the leaf. Chives leaf contained a lot of phytochemical compounds which is potential as an antioxidant and antilithogenesis. The objective of this research is to evaluate the antioxidant and antilithogenesis activities of chives leaf extract. Antioxidant activity was evaluated by using DPPH as a free radical scavenging method. Total phenol and total flavonoid content also determined by using Folin-Ciocalteu and aluminum chloride colorimetric assay. Antilithogenesis assay was measuring using atomic absorption spectrophotometry method by incubating the kidney stone using extracts of chives leaves at $37^{\circ} \mathrm{C}$ for 6 hours. The measurement of calcium was using acetylene-air flow at $422.7 \mathrm{~nm}$ wavelength. From the data obtained, the highest antioxidant activity was found in ethyl acetate extract (IC50: $236.51 \pm 0.08 \mathrm{ppm}$ ). The highest phenolic content was found in the ethanolic extract $(111.28 \pm 1.29 \mathrm{mg} / \mathrm{g}$ extract) while the total flavonoid was found in ethyl acetate extract $(34.64 \pm 1.60 \mathrm{mg} / \mathrm{g}$ extract). While, antilithogenesis activity showed that the best result was using $2.5 \%$ (E5) concentration with $95.55 \%$ solubility of calcium which obtained from ethyl acetate extract.Based on the above results, it can be concluded that chives leaf extracts have a potential and promising as an antioxidant and antilithogenesis sources
\end{abstract}

Keywords: Total Phenolic, Total Flavonoid, Antioxidant, $\mathrm{IC}_{50}$, Chives, Free Radicals, Antilithogenesis

○ RASĀYAN. All rights reserved

\section{INTRODUCTION}

Traditional medicinal plants have long been known by society long before the development of synthetic drugs. Phytochemical compounds are natural substances contained in plants that provide flavor, aroma color and pharmacological activity that is typical of the plant. ${ }^{1,2}$ Some properties of phytochemical compounds that function as antioxidants, boost the immune system, regulate blood pressure, lower cholesterol, antimetabolite syndrome (such as antidiabetic and antinephrolithiasis) and regulating blood sugar levels. ${ }^{3}$

Herbal drugs are the oldest sources for the preventing, medication, treatment and even diagnostic tools know to mankind. Most of the drugs commonly used today are the herbal origin. Herbal drugs are inexpensive and effective with fewer side effects. ${ }^{4,5}$ Consumption of adequate amounts of antioxidants is reported to decrease the incidence of many diseases, such as cardiovascular, cancer,osteoporosis, inflammation, nephrolithiasis and others. ${ }^{6}$

One of this useful plant is chives. Chives contained a lot of phytochemical compounds such as phenolic and flavonoids. ${ }^{7}$ Phenolic and flavonoids possess a wide spectrum of biochemical activities such as prevent blood clotting, antioxidants, breast cancer, anti-inflammatory and antihypertensive, antioxidant, antimutagenic, anticarcinogenic, gene expression, vaginal discharge, constipation and infectious germs in the intestines and speed up the blood flow. ${ }^{8-12}$

Rasayan J. Chem., 11(4), 1604-1608(2018)

http://dx.doi.org/10.31788/RJC.2018.1144067

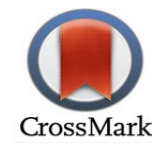


Former antilithogenesis activity of chives leaf has been reported that chives leaf infuse is a potential treatment for kidney stones. ${ }^{7}$ Because of that reasons, we will investigate the antioxidant and antilithogenesis activities from different chives (Allium schoenoprasum L.) leaf extracts and determine the total phenolic and total flavonoid content in chives leaf extracts.

\section{EXPERIMENTAL}

\section{Materials}

The materials were DPPH, gallic acid, folin-ciocalteau reagents, quercetin, aquades, organic solvent (ethanol, ethyl acetate and hexane), $\mathrm{Na}_{2} \mathrm{CO}_{3}, \mathrm{CH}_{3} \mathrm{COONa}, \mathrm{AlCl}_{3}$, methanol, human kidney stones, demineralized water (Bratack), nitric acid 65\% (Merck) and standard solution of calcium (1000 ppm).

\section{Preparation of Extracts}

Fresh chives leaf was collected from the local market in Perbaungan regency (North Sumatera, Indonesia) and authenticated by the Herbarium Medanense (No: 928/MEDA/2017). The dried leaves samples were crushed and grounded to obtain a finely divided powder.Maceration method was chosen to extract the chives leaf powder which is modified using organic solvent based on the diversity of organic solvents such as hexane, ethyl acetate and ethanol solvent. 2,000 g of powdered chives leaf are macerated using three organic solvents (hexane, ethyl acetate and ethanol) for 7 days, then filtered and do it continuously until the filtrate obtained is clear and colorless. ${ }^{13}$

\section{Determination of Total Phenolic and Total Flavonoid Content}

The total phenolic content was determined using Folin-Ciocalteu reagent and gallic acid as a reference compound. $0.1 \mathrm{~mL}$ of extract, $7.9 \mathrm{~mL}$ of distilled water and $0.5 \mathrm{~mL}$ of Folin-Ciocalteu reagent were mixed in a conical flask and then $3 \mathrm{~mL}$ of Na2CO3 was added and shaken for $90 \mathrm{~min}$ at room temperature. The absorbance was measured at $775 \mathrm{~nm}$ against distilled water as a blank. The total content of phenol is expressed in units of mg GAE / $\mathrm{g}$ of the sample extract (Sari, 2018; Singleton and Rossi, 1965).The flavonoid content was determined by using an $\mathrm{AlCl}_{3}$ method using quercetin as a reference compound. A volume of $2 \mathrm{~mL}$ of extract solution was added with $0.1 \mathrm{~mL} \mathrm{AlCl} 3,0.1 \mathrm{~mL} \mathrm{CH}_{3} \mathrm{COONa}_{3}$ and $2.8 \mathrm{~mL}$ distilled water and then incubated for $40 \mathrm{~min}$. After $40 \mathrm{~min}$ incubation, the mixture turns into yellow and the absorbance was measured at $431.5 \mathrm{~nm}$ against distilled water as a blank. The total flavonoid content is expressed in units of $\mathrm{mg} \mathrm{QE} / \mathrm{g}$ of the sample extract. ${ }^{2}$

\section{Determination of DPPH Free Radical Scavenging Activity}

The DPPH free radical-scavenging activity was determined using the standard method described by Sianipar, et al., (2018). Various concentration of extract was mixed with $0.5 \mathrm{mM}$ of DPPH in methanol. The solution was incubated for 30 mins at room temperature and dark condition. Ascorbic acid was used as positive control. After incubation, the absorbance was taken at $515 \mathrm{~nm}$ and calculated the $\%$ inhibition of DPPH radical. ${ }^{14-16}$ The test was carried out in triplicate for all type of extracts.

Percentage of inhibition $=\frac{\text { Absorbance control }- \text { Absorbance sample }}{\text { Absorbance control }} \times 100 \%$

\section{Experimental Design for in vitro Anti-lithogenesis Activity}

This research comprises nine groups, namely of E1-E6. Each group was treated as follows:

i. E1: $1 \%$ concentration of ethanol extract.

ii. E2: $2.5 \%$ concentration of ethanol extract.

iii. E3: $5 \%$ concentration of ethanol extract.

iv. E4: $1 \%$ concentration of ethyl acetate extract.

v. E5: $2.5 \%$ concentration of ethyl acetate extract.

vi. E6: $5 \%$ concentration of ethyl acetate extract.

Each concentration repeated 6 times for treatment with incubation and without incubation using kidney stones to check the level of calcium in the extract solution. Levels of dissolved calcium were calculated 
based on the standard calibration curve and measured by atomic absorption spectrophotometer at a wavelength of $422.7 \mathrm{~nm}$.

\section{Statistical Analysis}

Data were presented as mean \pm SD of triplicate determination. ${ }^{5,17}$

\section{RESULTS AND DISCUSSION \\ Total Phenolic and Total Flavonoid Content}

The results obtained in this study showed a significant level of phenolic and flavonoid content. Table-1 showed the result from the determination of total phenolic and flavonoid content. The results showed that the contents of phenolic were higher in the ethanolic extract $(111.28 \pm 1.29 \mathrm{mg})$ than other extracts by using the standard curve of gallic acid $\left(\mathrm{R}^{2}=0.9996\right)$, while the total flavonoid content showed that ethyl acetate extract $(34.64 \pm 1.60 \mathrm{mg})$ had the highest content by using quercetin standard curve $\left(\mathrm{R}^{2}=0.99941\right)$. The variation of phenolic and flavonoid compounds content in the extract depends on the influence of organic solvent on the extracted phytochemical compound. ${ }^{16}$

Table-1: Total Phenolic and Total Flavonoid Content of Chives Leaf Extract

\begin{tabular}{c|c|c}
\hline Chives Leaf Extract & $\begin{array}{c}\text { Total Phenolic Content } \\
\text { (mg GAE/g sample) }\end{array}$ & $\begin{array}{c}\text { Total Flavonoid Content } \\
\text { (mg QE/g sample) }\end{array}$ \\
\hline Ethanolic & $111.28 \pm 1.29$ & $23.07 \pm 0.16$ \\
Ethyl acetate & $107.68 \pm 0.52$ & $34.64 \pm 1.60$ \\
Hexane & $102.26 \pm 1.18$ & $20.7 \pm 4.24$ \\
\hline
\end{tabular}

Values are expressed as Mean \pm SEM, $\mathrm{n}=6 ; \mathrm{mg} \mathrm{GAE} / \mathrm{g}: \mathrm{mg} /$ Gallic Acid Equivalent; mg QE/g : mg Quercetin Equivalent

\section{DPPH Free Radical Scavenging Activity}

The result of the antioxidant activity of the different extracts (ethanolic, ethyl acetate and hexane) according to the polarity of the solvent was measured using the standard DPPH method. The data of antioxidant result are presented in the Table-2.

$\mathrm{IC}_{50}$ indicates that the test sample can cause a 50\% reduction of DPPH activity, this can be seen also from the color change of the thick purple test sample when DPPH added will turn into yellow if the test sample has a damping activity. The lower the $\mathrm{IC}_{50}$ value of an antioxidant the higher would be its free radical scavenging power. ${ }^{2,18}$

Chives leaf extract with ethyl acetate solvent has the highest antioxidant activity compared to leaf extract of kucai with ethanol and n-hexane solvent. This is because the bioactive compounds contained in chives leaf extract with an ethyl acetate solvent more active role as an inhibitor of free radical DPPH, in other words, bioactive compounds that act as DPPH free radical inhibitors from ethyl acetate extract of chives leaf can be extracted properly if using ethyl acetate. ${ }^{16,19}$ Based on the research, the total content of flavonoids in ethyl acetate extract was higher than the extract with other solvents. This is because the potential of antioxidant compound (flavonoid compound) is more dissolved in the ethyl acetate solvent, so that the highest DPPH free radical scavenging activity is also shown by the extract with the ethyl acetate solvent.

Table-2: Antioxidant Result from Different Extracts of Chives Leaf

\begin{tabular}{c|c|c|c}
\hline $\begin{array}{c}\text { Chives Leaf } \\
\text { Extract }\end{array}$ & $\begin{array}{c}\text { Concentration } \\
(\mathrm{ppm})\end{array}$ & $\begin{array}{c}\text { IC50 } \\
(\mathrm{ppm})\end{array}$ & $\begin{array}{c}\text { Percentage of } \\
\text { Scavenging (\%) }\end{array}$ \\
\hline Ethanolic & 400 & $313.67 \pm 0.06$ & 61.08 \\
\hline Ethyl acetate & 400 & $236.51 \pm 0.01$ & 78.37 \\
\hline Hexane & 400 & $359.22 \pm 1.28$ & 49.46 \\
\hline
\end{tabular}

Values are expressed as Mean \pm SEM, $n=6$

\section{In vitro Anti-litogenesis Activity}

The result of in vitro antilithogenesis activity using 2 extracts (ethanolic and ethyl acetate) showed in Table-3. The reason for using only two extracts was because the antioxidant result showed that ethanol 


\section{RASĀYAN J. Chem.}

Vol. 11 | No. 4 |1604 - 1608| October - December | 2018

and ethyl acetate extract of chives leaf showed the best result. The highest percentage of calcium solubility was found at concentration $2.5 \%$ (E5: ethyl acetate extract). Chives leaf extract can dissolve the calcium because of the potassium, phenolic and flavonoid content. The mechanism of calcium dissolving is because the location of potassium in the Volta's row to the left side from calcium, so potassium will get rid of potassium and calcium oxalate in kidney stones to join and will dissolve the calcium.Another factor is because of the phenolic and flavonoid which can inhibit kidney stone and dissolve the calcium compound in kidney stones by making a complex bond between the phenolicflavonoid with the calcium. ${ }^{5,20}$

Table-3: In vitro Anti-lithogenesis Activity Result

\begin{tabular}{c|c|c|c|c|c}
\hline No. & Code & $\begin{array}{c}\text { Calcium level without } \\
\text { incubation } \\
(\mu \mathrm{g} / \mathrm{ml})\end{array}$ & $\begin{array}{c}\text { Calcium level within the } \\
\text { incubation } \\
(\mu \mathrm{g} / \mathrm{ml})\end{array}$ & $\begin{array}{c}\text { Dissolved } \\
\text { Calcium }(\mu \mathrm{g} / \mathrm{ml})\end{array}$ & $\begin{array}{c}\text { Percentage of } \\
\text { Calcium } \\
\text { Solubility }(\%)\end{array}$ \\
\hline 1. & E1 & 4.2171 & 4.6029 & 0.3858 & 8.38 \\
\hline 2. & E2 & 4.3019 & 8.7783 & 4.4764 & 50.99 \\
\hline 3. & E3 & 7.6008 & 12.4503 & 4.8495 & 38.95 \\
\hline 4. & E4 & 1.1245 & 18.2554 & 17.1309 & 93.84 \\
\hline 5. & E5 & 1.8601 & 41.7895 & 39.9294 & 95.55 \\
\hline 6. & E6 & 1.9595 & 43.9522 & 41.9927 & 95.54 \\
\hline
\end{tabular}

\section{CONCLUSION}

This study showed the presence of antioxidant compounds such as phenolic and flavonoid. The ethyl acetate extract showed the highest antioxidant and antilithogenesis activities. Based on the results, chives (Allium schoenoprasum L.) is a potent source of antioxidant and antilithogenesis compounds.

\section{ACKNOWLEDGMENT}

The authors wish to thank Universitas Sumatera Utara through "Hibah Penelitian Terapan Talenta" Research Grant 2018, Number: 2590/UN5.1.R/PPM/2018 for financial support in the research on 16 March 2018.

\section{REFERENCES}

1. I. Iksen, M. Sc. Thesis, Department of Pharmaceutical Chemistry, Universitas Sumatera Utara, Medan, North Sumatera, Indonesia (2017).

2. M.P. Sari, B. Pharm. Thesis, Department of Pharmaceutical Chemistry, Universitas Sumatera Utara, Medan, North Sumatera, Indonesia (2018).

3. K. Sayuti, R. Yenrina, Natural and Synthetic Antioxidant, Andalas Univeristy Press, Padang, p. 7 (2015).

4. M. Manimala, W.A. Clement, M.A.A. Sheik, P. Purushoth. Int. J. Drug Dev. \& Res., 6(3),138 (2014).

5. G. Haro, S.M. Sinaga, I. Iksen, N. Nerdy, S. Theerachetmongkol, J. App. Pharm. Sci., 7(8), 222 (2017), DOI: 10.7324/JAPS.2017.70830

6. H. Winarsi, Natural Antioxidant and Free Radical, Kanisius, Yogyakarta, p. 10 (2007).

7. S.M. Sinaga, I. Iksen, G. Haro, S. Wardhany. Asian J. Pharm. Clin. Re.s, 11(3), 77 (2018), DOI: 10.22159/ajpcr.2018.v11i3.22851

8. N. Andarwulan, R.H.F. Faradila, Sayuran Fenolik Pada Bebearpa Sayura Indigenous dari Indonesia, SEAFAST Center, Bogor, p. 40 (2012).

9. L. Amalia, E.Y. Sukandar, R.M.A. Roesli, J.L Sigit. EXCLI Journal, 14(4), 411 (2015).

10. B. Jalkumar, R.A. Jasmine. Int. J. Pharm Tech Res., 9(3), 333 (2016).

11. A.E. Parvu, M. Parvu, L. Vlase, P. Miclea, A.C. Mot, R.S. Dumiitrescu. Journal of Physiology and Pharmacology, 65(2), 309 (2014).

12. U.R. Sachinm, R.P. Priyanka, R.M. Sagar, Int. J. PharmTech Res., 2(2), 1074 (2010).

13. Ditjen POM, Indonesia Pharmacopoeia, Indonesia Department of Health, Jakarta, p. 1067 (1995).

14. M.P. Sianipar, E. Suwarso, R.Rosidah. Asian J. Pharm. Clin. Res., 11(3), 81(2018), DOI: 10.22159/ajpcr.2018.v11i3.22382 
RASĀYAN $J$. Chem.

Vol. 11 | No. 4 |1604 - 1608| October - December | 2018

15. R. Rosidah, M.F. Yam, A. Sadikun, M.Z. Asmawi. Pharm. Biol., 46, 616 (2008), DOI: 10.1080/13880200802179642

16. G. Haro, I. Iksen, R.M. Rumanti, N. Marbun, R.P. Sari, R.P.J. Gultom. Rasayan J. Chem., 11(1), 232 (2018), DOI: 10.7324/RJC.2018.1112011

17. B. Togatorop, K.R. Sinaga, E. Suwarso, I. Iksen. Rasayan J. Chem., 11(2), 516 (2018), DOI: 10.7324/RJC.2018.1112011

18. P. Molyneux. Songklanakarin J. Sci. Technol., 26(2), 211 (2004).

19. N.C. Suryani, Thesis, Faculty of Pharmacy, University of Udayana, Bali, Indonesia (2015).

20. I. Iksen, G.. Haro, S.M. Sinaga. Int. J. PharmTech Res., 10(2), 099 (2017).

[RJC-4067/2018] 